\title{
Alien water lettuce (Pistia stratiotes L.) outcompeted native macrophytes and altered the ecological conditions of a Sava oxbow lake (SE Slovenia)
}

\author{
Martina Jakličํㅗ Špela Koren², Nejc Jogan ${ }^{3 *}$ \\ ${ }^{1}$ University Medical Centre, Zaloska 2, 1000 Ljubljana, Slovenia \\ ${ }^{2}$ Institute for Water of the Republic of Slovenia, Einspielerjeva ulica 6, 1000 Ljubljana, Slovenia \\ ${ }^{3}$ University of Ljubljana, Biotechnical Faculty, Department of Biology, Večna pot 111, 1000 Ljubljana, Slovenia
}

\begin{abstract}
Introduction of an invasive alien macrophyte water lettuce (Pistia stratiotes L.) radically changed the oxbow lake in Prilipe (SE Slovenia) which has thermal springs that enables the winter survival of this tropical invader. About 10 years after the first record of $P$. stratiotes, the number, abundance and biomass of indigenous and non-indigenous macrophytes as well as different abiotic parameters were measured. In that period, colonized sections ( $\sim 94 \%$ of the oxbow lake) were completely covered with water lettuce, and the only reservoirs of indigenous macrophyte species were the non-colonized areas (6\%). Research in 2011 found only a third of the previously recorded indigenous macrophytes, but then only in small section without $P$. stratiotes. Three of the species that disappeared were on the Red data list. In the colonized section a higher biomass was observed than in the non-colonized section because of high abundance of water lettuce which remained the only macrophyte. Due to the presence of $P$. stratiotes, the intensity of light penetrating into the depth and water circulation were reduced, as was the oxygen saturation of the water. In addition to the well documented vegetative propagation of $P$. stratiotes, a well-established and viable seed bank has been detected in the lake sediment and after winter floods also on lake banks. In the future, special attention should be given to the thermal water ecosystems in temperate climates since they can serve as stepping stones and recruitment centres for the establishment and spread of (sub-)tropical invasive species. Facing predicted climate change such local populations of invasive species can act as stepping stones for further dispersal.
\end{abstract}

Keywords: altering ecological conditions, non-indigenous macrophyte, outcompeting, thermal oxbow lake, transformer, tropical species, water lettuce

\section{Introduction}

Macrophytes have a great effect on nutrient cycling, the concentration of dissolved oxygen, on the light conditions in the water and on the biochemical reactions (Caraco and Cole 2002, Chamier et al. 2012). Diversity of macrophytes has been particularly affected by human activities and management in the last few decades. Introduction of non-indigenous macrophytes (i.e. alien plants) usually has consequences for ecosystem processes and results in changes of biodiversity, reduction in the value of water for human activities and has a great influence on the water quality (Caraco and Cole 2002, DAISIE 2009). In addition, alien plants can decrease or completely change indigenous macrophyte biodiversity (DAISIE 2009, Ramey 2009). A good exam- ple is the Canadian waterweed Elodea canadensis Michx., which outcompeted native macrophytes in Slovenian rivers (Jogan 2005). Tropical non-indigenous species can establish self-sustaining populations in temperate waters only if water temperature and regime are appropriate. Thermal water bodies have warmer water than non-thermal inland waters and consequently contain unique native fauna and flora (Castenholz 1973, Raab 1993, Kralj 2000, Zuellig et al. 2002, Laprida et al. 2006, Petutsching et al. 2008, Piazzini et al. 2010).

Water lettuce (Pistia stratiotes L.) is a floating macrophyte originating in South America (Chamier et al. 2012). It became a popular ornamental plant in aquaria and gar-

${ }^{\star}$ Corresponding author e-mail: nejc.jogan@bf.uni-lj.si 
den ponds and as a result of naturalization is one of the most widespread aquatic weeds in almost all tropical and subtropical regions with extreme biomass production (Labrada and Fornasari 2002, DAISIE 2009). In Europe, accidental release of water lettuce is often noticed, but a low number of localities have stable populations (Šajna et al. 2007, Brundu et al. 2012). The first record of water lettuce escape in Europe was in 1973 in the Netherlands (Mennema 1977), while later it occasionally also occurred in other European countries - France, south-west Spain and in Central Europe (Pyšek et al. 2002, Šajna et al. 2007). In Eastern Europe (Moscow and Astrakhan Oblast) it has been reported as an ephemerophyte (Lisicyna et al. 2009). Recently it became established in water channels in northern Italy (Brundu et al. 2012), while it has also been noticed in Serbia with casual occurrences in some thermal waters and one record in non-thermal waters in eastern Vojvodina but with very low frequency (Živković et al. 2019). Despite many sporadic records in the temperate region of Europe, winter survival has only been reported in some localities in Austria (Hartl et al. 1992), Hungary (Simon 2000), Slovenia (Šajna et al. 2007) and Italy (Ercolini 2008).

In warmer regions worldwide different ways of controlling the populations of water lettuce are used including chemical and physical methods, but no reports about total local eradication could be found (Cilliers et al. 1996, Diop and Hill 2009, Gherardi et al. 2011). Mitigation by biological control agents could be more successful (Cilliers et al. 1996, Ajuonu et al. 2009, Diop and Hill 2009, Baker et al. 2010), with the introduction of new competitive alien species, which might on the other hand, have additional impacts (usually negative) on native biodiversity (Lockwood et al. 2007).

The oxbow lake in Prilipe (SE Slovenia) used to be an ecosystem with high biodiversity and an important reservoir for freshwater fish. As such it has been recognized as a natural value of state importance and as an area of ecological importance. During winter, numerous bird species stop there, due to the lack of any ice covering in spite of the low winter temperatures (Mirt 2009). Floristic inventories before 2001 were made on the whole area of the oxbow lake and the first data of flora in the oxbow lake go back more than three decades (Seliškar 1984) and later on some field records are available from 1992 and 1997 when no alien macrophytes were found (Jogan, unpbl.). Water lettuce was first observed in this oxbow lake in 2001 (Hudoklin 2002, Haler 2005). Since then water lettuce regenerates a large population every spring and rapidly grows luxuriantly to cover almost the whole surface of the oxbow lake. In summer months only about $4 \%$ of the water surface in the eastern part of the oxbow lake is devoid of lettuce (Šajna et al. 2007). Water lettuce reproduces by vegetative propagation and also by producing viable seeds (Haler 2005; Šajna et al. 2007). It is able to survive winter conditions because of thermal springs (average temperature $15^{\circ} \mathrm{C}$ ) present in the oxbow lake (Haler 2005, Šajna et al. 2007). Only a small marginal part of the oxbow lake was not yet colonized with water lettuce due to low winter temperature (in average $8^{\circ} \mathrm{C}$ ) (Šajna et al. 2007). Local communities and fishermen tried to reduce growth of water lettuce using herbicide and physical removal. From 2003, there were several attempts to remove floating lettuce biomass mechanically but without great success (Haler 2005, Šajna et al. 2007). The fishermen used also floating wooden barrier to fence water lettuce spread locally, but it turned out to be only a short term solution until the first heavy rain.

The purpose of this study was to compare the Sava oxbow lake flora in Prilipe before and after colonization with water lettuce. Moreover, objectives were also to examine differences within colonized sections of the oxbow lake regarding water lettuce biomass, and physical and chemical parameters, as well as to compare colonized areas covered with water lettuce with non-colonized area with indigenous macrophytes. Further on we checked viability of seeds to assume their potential role in lettuce population persistence and spread.

\section{Materials and methods}

\section{Study area}

Slovenia is a country in the central part of Europe with a mostly temperate climate. The study site is located in the south-eastern part of Slovenia, near the village of Prilipe (vicinity of Brežice, $140 \mathrm{~m}$ a.s.l.); the oxbow lake is $4 \mathrm{~km}$ long and the average water depth is approximately $1.5 \mathrm{~m}$. It is one of the very few remaining oxbow lakes along the Sava River. In 1855, Čatež Spa has been established near the oxbow lake and today it is the largest natural spa in Slovenia (Ivankovič and Nosan 1973, Shawish 2004). This oxbow lake has a unique water temperature regime due to inflow from underground thermal springs and the outflow of warm water from the pools inside the Čatež Spa resort. The study area was divided into five sections A, B, C, D and E corresponding to water temperature gradient as already defined by Jaklič and Vrezec (2011) (Fig. 1), sections A to D are referred as "colonized sections" in further text. Water temperature decreases downstream from section A (average annual $\mathrm{T}_{\mathrm{w}}=35^{\circ} \mathrm{C}$ ) to section $\mathrm{E}$ (average annual $\mathrm{T}_{\mathrm{w}}=15^{\circ} \mathrm{C}$ ) (Tab. 1 ).

Tab. 1. Description of five sections of the Sava oxbow lake (data source: Jaklič and Vrezec 2011).

\begin{tabular}{cccccc}
\hline Section & Length $(\mathrm{m})$ & Average width $(\mathrm{m})$ & Average depth $(\mathrm{m})$ & Area $\left(\mathrm{m}^{2}\right)$ & Mean annual water temperature $\left({ }^{\circ} \mathrm{C}\right)$ \\
\hline A & 247 & 30 & 1.2 & 4417 & 35 \\
B & 543 & 35 & 1.5 & 11285 & 30 \\
C & 252 & 7 & 0.4 & 6670 & 25 \\
D & 252 & 35 & 1.7 & 19344 & 20 \\
E & 142 & 16 & 1.3 & 2795 & 15 \\
TOTAL & 1436 & & & 44511 & \\
\hline
\end{tabular}




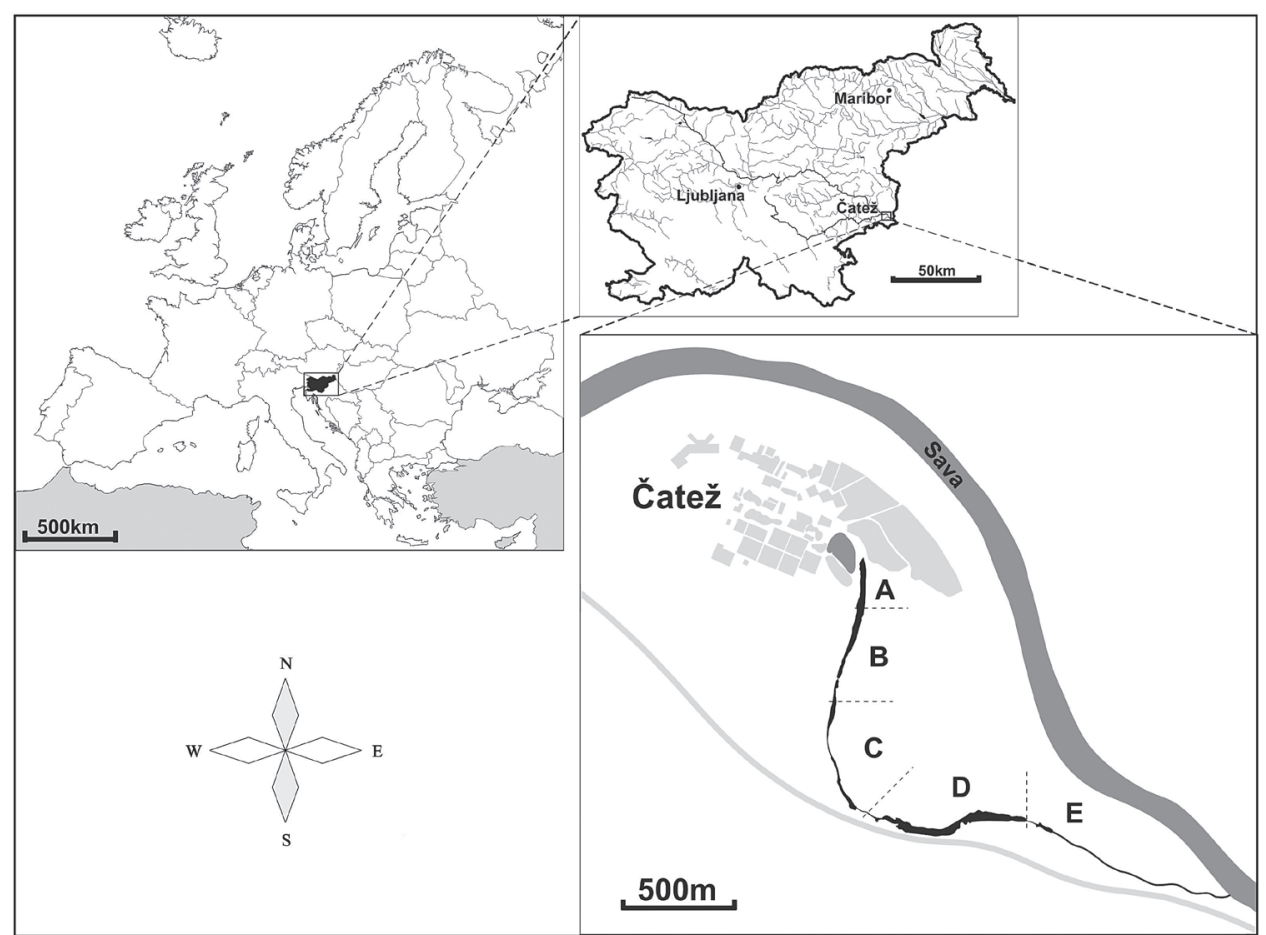

Fig. 1. Study area placed in European and Slovenian perspective (upper sections), the oxbow lake is marked black (lower right section). The Sava River is colored in grey. The Sava oxbow lake is divided into five sections A to E corresponding to a water temperature gradient as defined by Jaklič and Vrezec 2011.

\section{Sampling and analyses}

In 2009 and 2010 a detailed study of macrophytes has started. Sampling was performed seasonally in July and October 2009, and in January and May 2010. In each section a census of macrophyte flora (emergent, floating and submerged) was done. Five biomass sub-samples were taken using a quadrate $\left(1 \mathrm{~m}^{2}\right)$. All macrophytes were identified according to Martinčič et al. (2007), counted and weighted. Each subsample of each macrophyte species was separately washed with distilled water and dried at $60^{\circ} \mathrm{C}$ up to the constant weight. The density of macrophytes was expressed as number of plants per $\mathrm{m}^{2}$, and fresh and dry biomass were expressed in $\mathrm{kg}$ per $\mathrm{m}^{2}$.

As during the summer the water surface of the colonized sections is completely covered with water lettuce, the available aerial photos from the past were used to check when the lettuce population exploded.

Sub-samples for water quality were collected in four periods. In the middle of each section $1 \mathrm{~L}$ of water was sampled along the depth gradient. Anions $\left(\mathrm{Cl}^{-}, \mathrm{NO}_{2}^{-}, \mathrm{NO}_{3}{ }^{-}, \mathrm{SO}_{4}{ }^{2-}\right.$, $\left.\mathrm{PO}_{4}{ }^{3-}\right)$ and cations $\left(\mathrm{Na}^{+}, \mathrm{K}^{+}, \mathrm{Ca}^{+}, \mathrm{Mg}^{+}, \mathrm{NH}_{4}^{+}\right)$were measured by ion chromatography (Metrohm, 761 Compact IC). Abiotic parameters water temperature $\left({ }^{\circ} \mathrm{C}\right)$, oxygen saturation (\%), concentration of dissolved oxygen $\left(\mathrm{mg} \mathrm{L}^{-1}\right)$ and $\mathrm{pH}$ were measured in the middle of each section with a Multi 340i measuring instrument (WTW GmbH, Weilheim). Transmitted daylight in the depth between surface and $1 \mathrm{~m}$ depth was measured only once in July in section E and B with a digital light meter (LI 1000; LI-COR; USA; range 0 - 1000 lux) and expressed as percentage of the daylight (\%) measured just above the water.
In March 2010 dried plants of water lettuce on the banks of the oxbow lake in section D were collected (Fig. 2a, b) and from them 25 seeds were taken and set for germination in regular tap water in growth chambers with $20^{\circ} \mathrm{C}$ and $16 / 8$ h day/night photoperiod and $60 \%$ of air humidity (Fig. $2 \mathrm{c}$ ).

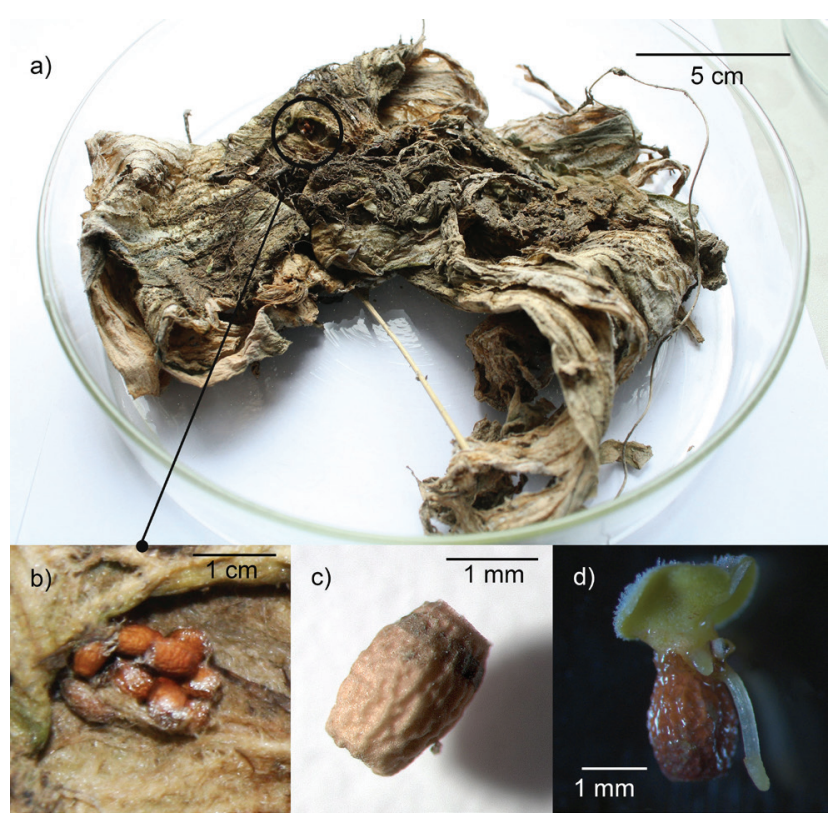

Fig. 2. The dried plant of water lettuce collected from the bank of the Sava oxbow lake in March 2010 (a), the seeds attached in groups on the bottom side of the oldest leaves (b), typical barrel shaped seed (c), germinating seed after one month in growth chambers (d). 


\section{Statistical analysis}

Parametric tests (analysis of variance, ANOVA with post-hoc test) were used when the data met assumptions for such tests (i.e. normality/ homoscedasticity). In cases when both raw and transformed data violated these assumptions, nonparametric tests were used instead.

Post-hoc tests, conducted after one-way ANOVAs, showed significant effects of experimental temperature within each group (Species or Sections). In the case of equal variances, the Tukey HSD test was used and if Levene's test of equality of variances indicated the variances were not equal, the Dunnett T3 test was used. Tukey's post-hoc test was used to determine if significant differences occurred among sections from the same sampling sites at each sampling month (season), which groups differed significantly $(P<0.05)$ in their numbers and biomass.

After comparison of all biometrical measurements, we tested differences within sections A to D (colonized with water lettuce) and a non-colonized section (section E) in biometrical measurements. Student $t$-test was used to test the differences between colonized and non-colonized sections of the oxbow lake.

All measured variables were divided into two groups: biometrical variables (number of species, freshwater biomass, dry biomass and number of plants) and water quality variables (physical and chemical). The variations among sampling sections was explored with forward stepwise discriminant analysis using the module in STATISTICA v. 12.0 software (STATISTICA 1995) with significance level for the analyses set at $\mathrm{P}=0.05$.

Correlations between biometrical measurements of water lettuce and abiotic parameters were given, calculated with Spearman correlations. Statistical analyses were performed using the statistical program SPSS 20.0 (SPSS Inc. Chicago, IL, USA) with a level of significance of $\mathrm{P}<0.05$.

\section{Results}

\section{Changes in floristic structure}

In the oldest floristic report of the discussed area (Seliškar 1984) four floating or submerged macrophytes were recorded: Ceratophyllum demersum, Potamogeton natans, $P$. pectinatus and Lemna minor but the results were incomplete because the oxbow lake was not the main focus of the floristic mapping of the area. In 1984 (Seliškar 1984), 1992 and 1997 (unpbl. Jogan), no alien macrophytes were found, only indigenous freshwater plants were widespread throughout the whole oxbow lake (see Tab. 2). Out of 10 previously reported macrophytes, four were listed in the Red data list as vulnerable and one as endangered (Anonymous 2002). The first non-indigenous macrophyte, $P$. stratiotes was recorded in the oxbow lake in 2001 (Hudoklin 2002, Haler 2005). In 2005, four native macrophytes (C. demersum, Myriophyllum spicatum, Najas marina and Trapa natans) were still present in the oxbow lake (Šajna et al. 2007) (Tab. 2). A comparison of available aerial photos of colonized sections in
Tab. 2. List of macrophytes in the Sava oxbow lake before (1984, $1992,1997)$ and after $(2009,2010)$ the expansion of water lettuce (+ = present; $-=$ not present). Red data list (Anonymous, 2002) status: $\mathrm{V}$ - vulnerable taxon, $\mathrm{E}$ - endangered taxon.

\begin{tabular}{|c|c|c|c|c|}
\hline Macrophytes & $\begin{array}{l}\text { Red data } \\
\text { list }\end{array}$ & Native & Before & After \\
\hline Berula erecta (Huds.) Coville & . & Yes & + & - \\
\hline Ceratophyllum demersum L. & $\mathrm{V}$ & Yes & + & + \\
\hline Lemna gibba L. & $\mathrm{V}$ & Yes & - & + \\
\hline Lemna minor $\mathrm{L}$. & . & Yes & + & + \\
\hline Myriophyllum spicatum L. & $\mathrm{V}$ & Yes & + & - \\
\hline Najas marina L. & $\mathrm{V}$ & Yes & + & - \\
\hline Pistia stratiotes L. & . & No & - & + \\
\hline Potamogeton crispus L. & . & Yes & + & - \\
\hline Potamogeton natans L. & . & Yes & + & - \\
\hline Potamogeton pectinatus $\mathrm{L}$. & . & Yes & + & - \\
\hline $\begin{array}{l}\text { Potamogeton trichoides } \\
\text { Cham. et Schltdl. }\end{array}$ & E & Yes & + & - \\
\hline Trapa natans L. & $\mathrm{V}$ & Yes & + & + \\
\hline
\end{tabular}

the years before and after the introduction of $P$. stratiotes is presented in Fig. 3, confirming that the lettuce population exploded between 1995 and 2003, which corresponds to the field records.

In this study, almost no indigenous macrophytes were found in colonized sections. Indigenous macrophytes were observed only in section $\mathrm{E}$, the coldest part of the oxbow lake (only a small population with negligible biomass of Lemna gibba in section D (Tab. 2). Lemna gibba was discovered in the oxbow lake for the first time in 2010 but there is a strong possibility that it could have been overlooked previously due to its similarity with L. minor, which had already been reported (Šajna et al. 2007). So today instead of 10 macrophyte species (five of them at the Red data list) there are only five species (three on the Red data list), the most abundant of them water lettuce, which has obviously outcompeted several native taxa and caused local extinction.

\section{Differences in quantitative biotic parameters among sections}

Number of plants and their biomass differed statistically among sections $\left(\mathrm{F}_{4.42}=4.1, \mathrm{P}=0.006\right)$ and species $\left(\mathrm{F}_{4.42}\right.$ $=93.8, \mathrm{P}<0.001)$. Post-hoc tests conducted after one-way ANOVAs showed that plants were the most abundant in the section $\mathrm{E}$ (Dunnett T3 post-hoc test, $\mathrm{P}=0.003$ ). The highest number of individual plants was counted for species $L$. gibba and the lowest for T. natans, both in section E (Dunnett T3 post-hoc test, $\mathrm{P}<0.003)$. Freshwater biomass differed among sections $\left(\mathrm{F}_{4.42}=8.3, \mathrm{P}<0.001\right)$ and species $\left(\mathrm{F}_{4.42}\right.$ $=7.9, \mathrm{P}<0.001)$. Statistically the highest freshwater and dry biomass were measured in the sections $\mathrm{C}$ and $\mathrm{D}$ (Dunnett T3 post-hoc test, $\mathrm{P}=0.003, \mathrm{P}=0.04$ ) as a result of only one species, $P$. stratiotes (Dunnett T3 post-hoc test, $\mathrm{P}=0.008$ ). Dry biomass differed significantly among sections $\left(\mathrm{F}_{4.42}=\right.$ $5.1, \mathrm{P}=0.001$ ), with the highest mass in section $\mathrm{D}$ (Dunnett T3 post-hoc test, $\mathrm{P}=0.001$ ), as a consequence of the $P$. stratiotes abundance. 


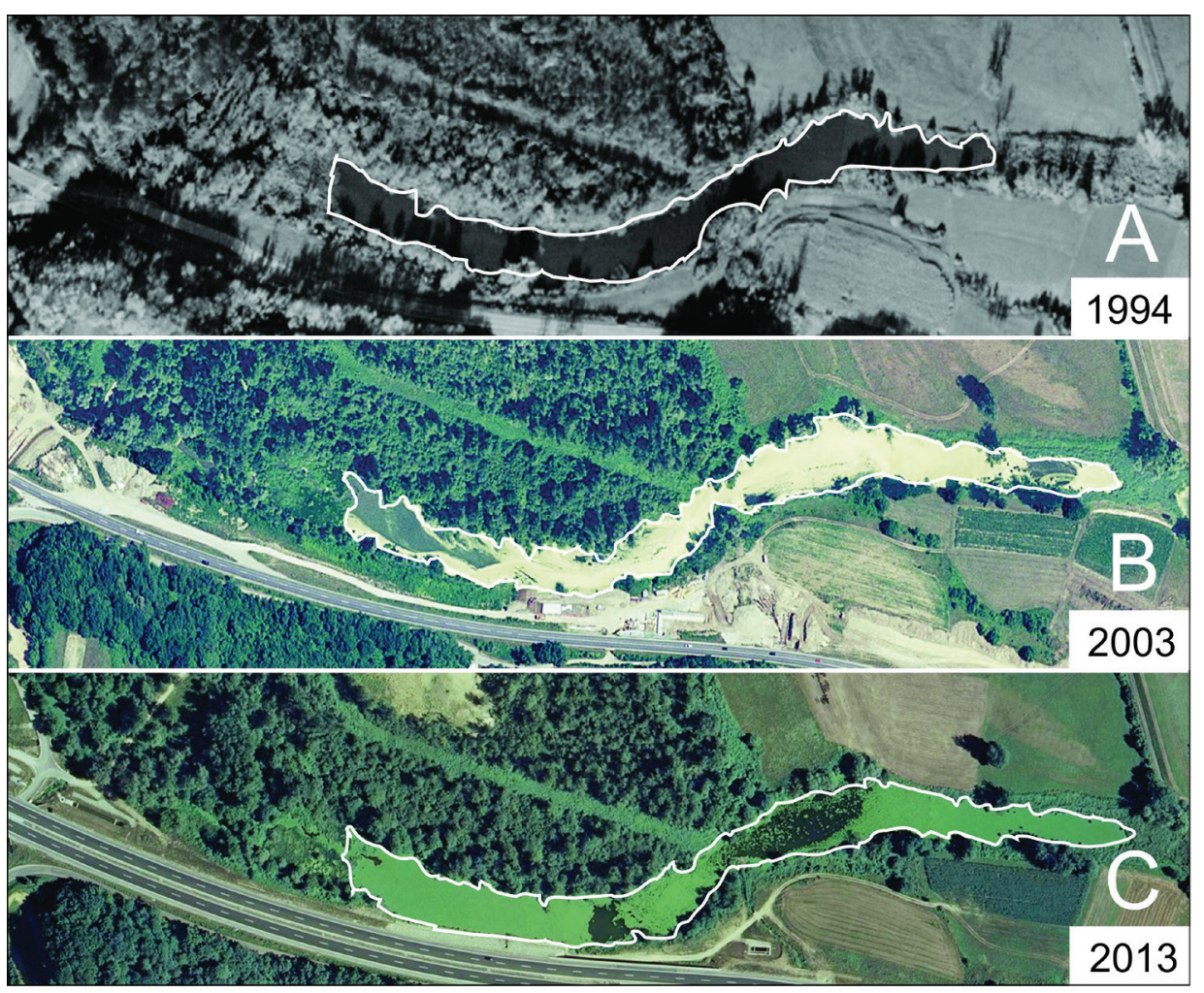

Fig. 3. Section D of the Sava oxbow lake before water lettuce was introduced (A, year 1994) and complete coverage after colonization (B, year 2003 and C, year 2013).

The number of individual plants did not differ among seasons $\left(\mathrm{F}_{3.43}=1.2, \mathrm{P}>0.05\right)$, while differences were observed in biomass (fresh biomass: $\mathrm{F}_{3.43}=7.4, \mathrm{P}<0.001$, dry biomass: $\left.\mathrm{F}_{3.43}=4.9, \mathrm{P}=0.005\right)$. Biomass was higher in summer due to the abundance of water lettuce and the lowest in the winter months (Tukey HSD post-hoc test, $\mathrm{F}_{3.43}=9.2, \mathrm{P}<0.001$ ) (Fig. 4 . Mean freshwater biomass of all sampled macrophytes among seasons and sections. Sections A to E are shown in Fig. 1.).

Within colonized sections, because the number of plant individuals (Kruskal-Wallis tests, $\mathrm{P}>0.05$ ), and the biomass (fresh and dry: Kruskal-Wallis test, $\mathrm{P}>0.05$ ) did not statistically differ, the data were pooled in further analyses. We did not confirm differences in number of plant individuals comparing the colonized and non-colonized sections $\left(\mathrm{F}_{1.40}\right.$ $=0.02, \mathrm{P}>0.05)$, while the sections differed in biomasses $\left(\mathrm{F}_{1.40}=86.5, \mathrm{P}<0.001\right.$ for fresh biomass and $\mathrm{F}_{1.40}=8.3, \mathrm{P}=$ 0.003 for dry biomass). The average fresh biomass of water lettuce in colonized sections was four times higher than the average fresh biomass of native macrophytes in section $\mathrm{E}$ $\left(8.6 \mathrm{~kg} \cdot \mathrm{m}^{-2}\right.$ and $\left.0.63 \mathrm{~kg} \cdot \mathrm{m}^{-2}\right)$. In section $\mathrm{E}$, of the native macrophytes, $C$. demersum had the highest fresh biomass (1.5 $\left.\mathrm{kg} \cdot \mathrm{m}^{-2}\right)$ and $L . g i b b a$ the lowest $\left(0.01 \mathrm{~kg} \cdot \mathrm{m}^{-2}\right.$ in the peak of high growth season).

\section{Differences in abiotic parameters among sections}

According to discriminant function analysis the Mahalanobis distances between group centroids differed significantly between sections (Wilks' lambda $=0.019, \mathrm{~F}_{4.19}=2.51$, $\mathrm{P}<0.05)$. Only the first two functions were statistically sig-

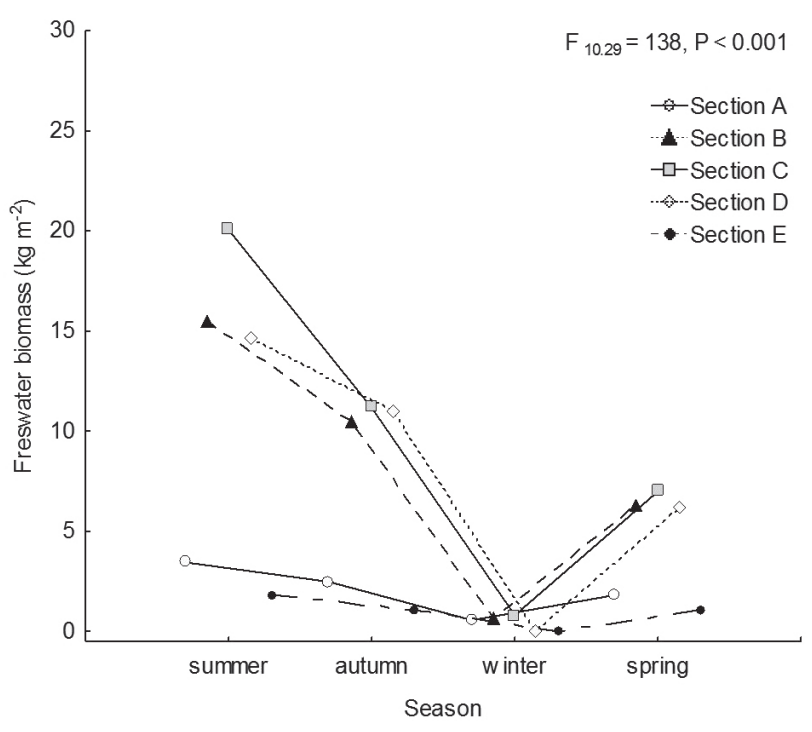

Fig. 4. Mean freshwater biomass of all sampled macrophytes among seasons and sections. Sections A to E are shown in Fig. 1.

nificant $(\mathrm{P}<0.001)$, and only they were included in further analysis. The first discriminant function explained $65 \%$ of variation, showing the separation as a result of water temperature and the second discriminant function explained additional $29 \%$ of the variation with $\mathrm{NO}_{3}{ }^{-}$(Fig. 5). Both variables having significant discriminating effects (Partial Wilks' lambda $=0.343, \mathrm{~F}_{4.19}=4.8, \mathrm{P}<0.05$ and Partial Wilks' lambda $\left.=0.41, \mathrm{~F}_{4.10}=3.5, \mathrm{P}<0.05\right)$.

Water temperature was significantly higher in the colonized section (annual average $\mathrm{T}=27.6 \pm 6.0^{\circ} \mathrm{C}$ ) than in the 


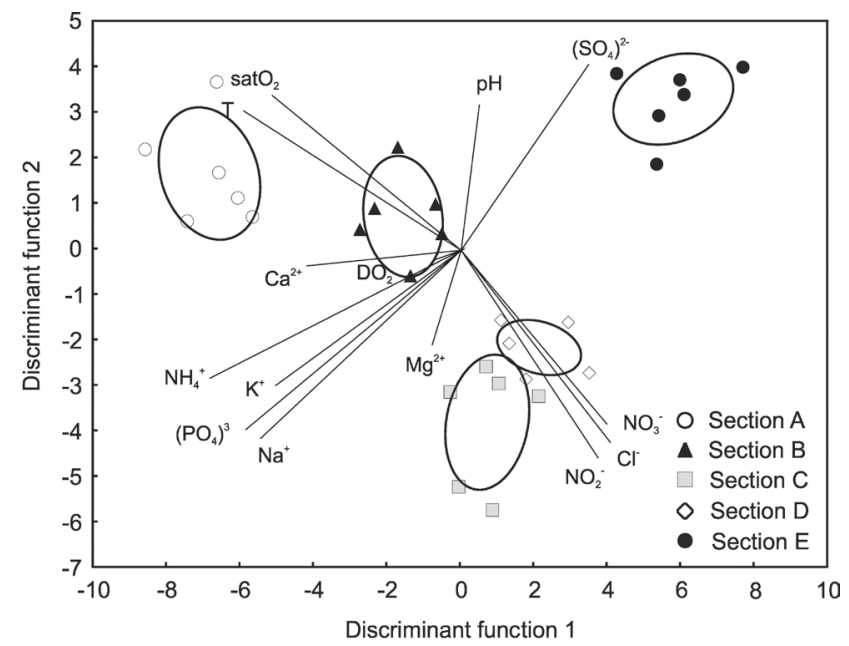

Fig. 5. Discrimination of the colonized (A-D) and non-colonized section (E) in the oxbow lake by the first two discriminant functions. Input data matrix consisted of all measured abiotic parameters, projections of primary variables shown as bi-plot. Sections A to E are shown in Fig. 1.

non-colonized section (annual average $\mathrm{T}=15.8 \pm 5.3{ }^{\circ} \mathrm{C}$ ) $\left(\mathrm{F}_{1.28}=19.2, \mathrm{P}<0.001\right)$, with the highest water temperature in section $\mathrm{A}\left(36.1 \pm 2.5^{\circ} \mathrm{C}\right)$. The colonized section had significantly lower oxygen saturation (average annual $41.3 \pm$ $22.4 \%$ vs. $67.5 \pm 14.5 \%$ ) and concentration of dissolved oxygen (average annual $4.1 \pm 1.2 \mathrm{mg} \mathrm{L}^{-1}$ vs. $6.0 \pm 2.7 \mathrm{mg} \mathrm{L}^{-1}$ ) than the non-colonized section $\left(\mathrm{F}_{1.28}=43.1, \mathrm{P}<0.001\right.$ and $\mathrm{F}_{1.28}=11.9, \mathrm{P}=0.002$ ). Concentration of dissolved oxygen was on average below $5 \mathrm{mg} \mathrm{L}^{-1}$ in sections A-D and $7.8 \pm 4.2$ $\mathrm{mg} \mathrm{L}^{-1}$ in section $\mathrm{E}$. Variables $\mathrm{pH}$, concentration of cations, and concentration of two anions $\left(\mathrm{Cl}^{-}\right.$and $\left.\mathrm{PO}_{4}{ }^{3-}\right)$ were not significantly different in the colonized and the non-colonized section. Higher concentration of $\mathrm{NO}_{2}{ }^{-}$and $\mathrm{NO}_{3}{ }^{-}$were measured in the colonized section (especially in section $\mathrm{C}$ and $\mathrm{D})$, than in the non-colonized section $\left(\mathrm{F}_{1.28}=2.9, \mathrm{P}=\right.$ 0.040 for $\mathrm{NO}_{2}^{-}, \mathrm{F}_{1.28}=6.3, \mathrm{P}=0.011$ for $\left.\mathrm{NO}_{3}{ }^{-}\right)$. Concentration of $\mathrm{SO}_{4}^{2-}$ was on average significantly higher in the colonized section (with the maximum in section $\mathrm{A}-\mathrm{C}$ ) than in the non-colonized section $\left(\mathrm{F}_{1.28}=10.6, \mathrm{P}=0.003\right)$.

Water temperature was correlated significantly with number of water lettuce plants $\left(\mathrm{r}_{\mathrm{s}}=0.583, \mathrm{P}<0.05\right)$, fresh $\left(r_{s}=0.550, P<0.05\right)$ and dry biomass $\left(r_{s}=0.532, P<0.05\right)$, while no correlation was found between ion concentrations and number of plants, fresh or dry biomass of water lettuce $(\mathrm{P}>0.05)$.

The non-colonized section statistically differed from the colonized sections (Mann-Whitney $\mathrm{U}$ test, $\mathrm{P}<0.001$ ) in water column light conditions (percentage of daylight at a certain depth; Fig. 6a). The non-colonized section had more than $50 \%$ higher percentage of light than the colonised (Fig. 2). In colonized sections the percentage of daylight was nearly $0 \%$ at $10 \mathrm{~cm}$ depth and deeper. Oxygen saturation was not different down to the $50 \mathrm{~cm}$ water depth (Fig. 6b), while a clearly lower saturation was measured in the colonized section deeper than $50 \mathrm{~cm}$ (Fig. 2) obviously due to the decay of biomass.

\section{Seeds}

We observed that larger plants of water lettuce died in winter, when water and air temperature fell. With gradual decay of dead plants, seeds were released and they accumulated in the sludge. In axils of oldest leaves where inflorescences developed during summer seeds were concentrated almost without remnants of other inflorescence parts that have already been completely decomposed (Fig. 2b). We found that approximately $40 \%$ of seeds germinated in regular tap water in growth chambers (Fig. 2d). In the spring in the oxbow lake we also noticed young floating seedlings derived from germinated seeds.
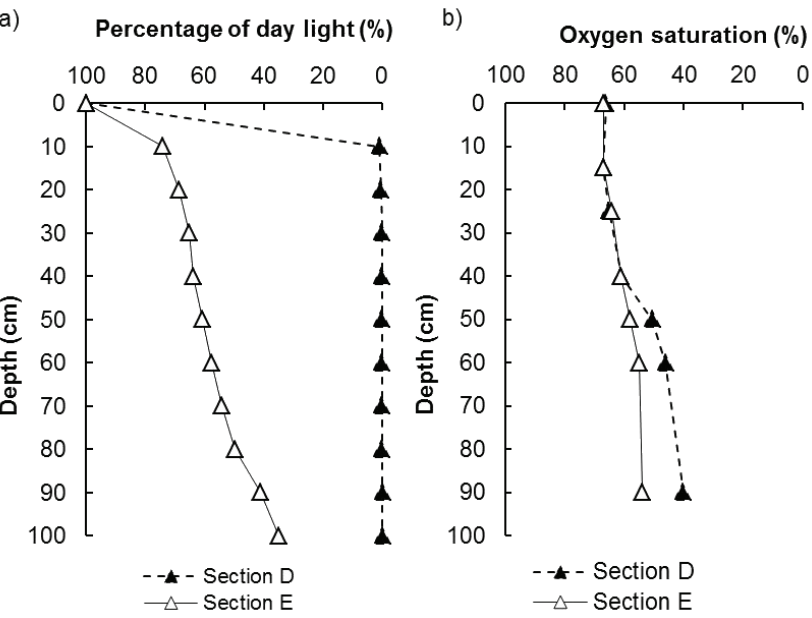

Fig. 6. Percentage of daylight (a) and oxygen saturation (b) in the water column in a colonized (section D) and the non-colonized section (section E) of the Sava oxbow lake in 2010.

\section{Discussion}

Prilipe oxbow lake in Slovenia is one of the few places in continental Europe where overwintering of water lettuce has been reported for almost two decades. Out of 10 previously recorded macrophytes only a third have survived colonization by water lettuce but at the same time their populations are reduced and limited to the $6 \%$ of the oxbow lake that has not been colonized (section E, area of $0.28 \mathrm{ha}$ ). Haler (2005) has already concluded that water lettuce outcompeted native macrophytes in the lake and we can only reconfirm that in 2010. The presence of four previously recorded native macrophytes (Seliškar 1984, Šajna et. al. 2007), were confirmed in our study. We also observed Lemna gibba, for the first time, but populations of Berula erecta, Myriophyllum spicatum, Najas marina, Potamogeton crispus, P. natans, P. pectinatus and $P$. trichoides had became locally extinct. So obviously invasion by water lettuce has caused a degradation of the local macrophyte community and damaged biodiversity, particularly so because three of the mentioned native macrophytes are listed in the Red data list (Anonymous 2002).

Macrophyte beds have generally high primary production and can thus be an important source of organic matter, supporting higher trophic levels and influencing the net metabolism of aquatic systems. As has been stated by Caraco and Cole (2002), dense canopies of floating macrophytes can prohibit 
gas exchange and make oxygen depletion more severe, some floating macrophytes can release much of their photosynthetically produced oxygen directly into the atmosphere rather than into the water column. Exactly this can explain the situation with water lettuce in the oxbow lake, where after colonization the ecological conditions were radically changed, which puts this species among invasive alien transformers (Pyšek et al. 2002). During the vegetation period, when the studied water lettuce population expanded exponentially, concentration of dissolved oxygen (DO) in the water decreased to less than $5 \mathrm{mg} \mathrm{L}^{-1}$. That can have a negative impact upon sensitive species of fish and invertebrates and can also impact nitrification/denitrification cycles (Urbanič and Toman 2003). Average concentration of $\mathrm{DO}$ was lowest in section $\mathrm{C}$, where the oxbow lake is the most shallow.

Comparison of oxygen saturation in the covered part and the uncovered part of the oxbow lake showed that below 0.5 $m$ depth low oxygen quantity was measured due to organic matter decay on the bottom and scarce light conditions. Since the light conditions were completely changed due to water lettuce, no other macrophytes were able to thrive below $10 \mathrm{~cm}$ of water depth.

In Europe, sites such as thermal water bodies and reservoirs for hydroelectric power stations have a high potential for water lettuce naturalization. Nevertheless, in the last years a few ephemeral occurrences of water lettuce were observed about $20 \mathrm{~km}$ down the Sava River, in the Sava-Strmec Special Reserve (Boršić and Rubinić 2018). But in the direct vicinity of the oxbow lake (about $11 \mathrm{~km}$ towards NW), there is a warm section of Sava River due to outflow from a nuclear power station. Further on, in the near future, close to the oxbow lake a hydropower plant is planned on the Sava River, which might

\section{References}

Ajuonu, O., Byrne, M., Hill, M., Neuenschwander, P., Korie, S., 2009: The effect of two biological control agents, the weevil Neochetina eichhorniae and the mirid Eccritotarsus catarinensis on water hyacinth, Eichhornia crassipes, grown in culture with water lettuce, Pistia stratiotes. Biocontrol 54, 155-162.

Anonymous 2002: Rules on the inclusion of endangered plant and animal species in the Red List. Uradni list RS 82/2002, 8893 (in Slovenian).

Baker, P., Zimmanck, F., Baker, S.M., 2010: Feeding rates of an introduced freshwater gastropod Pomacea insularum on native and nonindigenous aquatic plants in Florida. Journal of Molluscan Studies 76, 138-143.

Boršić, I., Rubinić, T., 2018: First record of Pistia stratiotes L. (Araceae) in Croatia, with the consideration of possible introduction pathways. In: Jelaska, S.D. (ed.), Zbornik sažetaka 3. Hrvatskog simpozija o invazivnim vrstama, 96. Hrvatsko ekološko društvo, Zagreb.

Brundu, G., Stinca, A., Angius, L., Bonanomi, G., Celesti-Grapow, L., D'Auria, G., Griffo, R., Migliozzi, A., Motti, R., Spigno, P., 2012: Pistia stratiotes L. and Eichhornia crassipes (Mart.) Solms.: emerging invasive alien hydrophytes in Campania and Sardinia (Italy). European and Mediterranean Plant Protection Organization 42, 568-579.

Caraco, N.F., Cole, J.J., 2002: Contrasting impacts of a native and alien macrophyte on dissolved oxygen in a large river. Ecological Applications 12, 1496-1509. provide a new potential habitat for water lettuce. In the warmer conditions, at least during the summer months, water lettuce can become a real pest of accumulation reservoir.

We may also assume that predicted climate change causing general warmer conditions might create new problems: the species may extend its habitat range and in such case the oxbow lake can serve not only as a stepping-stone to rivers and other oxbow lakes of Central Europe, but also the source of a water lettuce population partly adapted to the European climatic conditions.

From our results we can conclude, that even in temperate regions, in thermal water bodies, water lettuce establishment is possible. It can outcompete all the native macrophytes, radically change light penetrating conditions in water, its cyclic production of biomass is several fold bigger than of native macrophytes and in the following seasons decay of dead biomass depletes oxygen and raises $\mathrm{NH}_{4}{ }^{+}$concentration in the deeper parts of the water, which can further influence the living conditions of fauna. The oxbow lake, one of the few remaining along the Sava River, which was once an important reservoir of local biodiversity of wetland organisms, is today only a good example of the complete local destruction of biodiversity as a result of the irresponsible release of a tropical aquarium plant into the nature.

\section{Acknowledgements}

We wish to thank those colleagues who have helped us to collect plants. Many thanks also to the anonymous reviewers whose suggestions and corrections substantially improved the text.

Castenholz, R.W., 1973: Ecology of blue-green algae in hot springs. In: Carr, N.G., Whitton, B.A. (eds.), The biology of blue-green algae, 379-414. Blackwell Scientific Publications, Oxford.

Chamier, J., Schachtschneider, K., Le Maitre, D.C., Ashton, P.J., Van Wilgen, B.W., 2012: Impacts of invasive alien plants on water quality, with particular emphasis on South Africa. Water SA 38, 345-356.

Cilliers, C.J., Zeller, D., Strydom, G., 1996: Short- and long-term control of water lettuce (Pistia stratiotes) on seasonal water bodies and on a river system in the Kruger National Park, South Africa. Hydrobiologia 340, 173-179.

DAISIE 2009: Handbook of alien species in Europe. Series: Invading nature. Springer series in invasion ecology 3. Springer, Dordrecht.

Diop, O., Hill, M.P., 2009: Quantitative post-release evaluation of biological control of Pistia stratiotes Linnaeus (Araceae) by the weevil Neohydronomus affinis Hustache (Coleoptera: Curculionidae) in Senegal. African Journal of Aquatic Science 34, 35-44.

Ercolini, P., 2008: Pistia stratiotes L. (Alismatales: Araceae) in Versilia (Toscana nord-occidentale). Biologia Ambientale 22, 45-49.

Gherardi, F., Robert Britton, J., Mavuti, K.M., Pacini, N., Grey, J., Tricarico, E., Harper, D.M., 2011: A review of allodiversity in Lake Naivasha, Kenya: Developing conservation actions to protect East African lakes from the negative impacts of alien species. Biological Conservation 144, 2585-2596. 
Haler, M., 2005: Occurrence, colonization and survival of water lettuce (Pistia stratiotes L.) in thermal waters of temperate zone. BSc thesis. Faculty of Education, Department of Biology. University of Maribor, Maribor (in Slovenian).

Hartl, H., Kniely, G., Leute, H.G., Niklfeld, H., Perko, M., 1992: Anhang 4: Pflanzen der Villacher Therme In: Seger, M. (ed.), Verbreitungsatlas der Farn- und Blütenpflanzen Kärnten, 411-412. Hera, Klagenfurt.

Hudoklin, A., 2002: Tropical water lettuce has suffocated the oxbow lake! Dolenjski list 47, 32 (in Slovenian).

Ivankovič, J., Nosan, A., 1973: Hydrogelology of Terme Čatež. Geologija 23, 353-368 (in Slovenian).

Jaklič, M., Vrezec, A., 2011: The first tropical alien crayfish species in European waters - the redclaw Cherax quadricarinatus (von Martens, 1868) (Decapoda, Parastacidae). Crustaceana 84, 651-665.

Jogan, N., 2005: Invasive alien species and wetlands. In: Beltram, G. (ed.), The Ramsar Convention and Slovenian wetlands, 7379. Minstrstvo za okolje in prostor, Ljubljana (in Slovenian).

Kralj, P., 2000: Thermal and mineral waters in north-eastern Slovenia. Environmental Geology 39, 488-500.

Labrada, R., Fornasari, L., 2002: Weed management of the worst aquatic weeds in Africa. Efforts and achievements during the period 1991-2001. FAO, Rome.

Laprida, C., Diaz, A., Ratto, N., 2006: Ostracods (Crustacea) from thermal waters, southern Altiplano, Argentina. Micropaleontology 52, 177-188.

Lisicyna, L.I., Papačenkov, V.G., Artemenko, V.I., 2009: Macrophyte flora of the Volga River basin. Tovariščestvo naučnyh izdanij KMK, Moskva (in Russian).

Lockwood, J.L., Hoopes, M., Marchetti, M., 2007: Invasion Ecology. Blackwell Publisher, Oxford.

Martinčič, A., Wraber, T., Jogan, N., Podobnik, A., Turk, B., Vreš, B., Ravnik, V., Frajman, B., Krajšek, S.S., Trčak, B., Bačič, T., Fischer, M.A., Eler, K., Surin, B., 2007: Small flora of Slovenia: determination key for ferns and seed plants. Tehnična založba Slovenije, Ljubljana (in Slovenian).

Mennema, J., 1977: Is water lettuce (Pistia stratiotes L.) becoming a new aquatic weed in the Netherlands? Natura Netherlands 74, 187-190.

Mirt, T., 2009: Battle with water lettuce. Proteus 71, 352-357 (in Slovenian).
Petutsching, V.J., Honsig-Erlenburg, W., Pekny, R., 2008: Zum aktuellen Flusskrebs- und Fischvorkommen des Warmbaches in Villach. Carinthia II 198/118, 95-102.

Piazzini, S., Lori, E., Favilli, L., Cianfanelli, S., Vanni, S., Manganelli, G., 2010: A tropical fish community in thermal waters of southern Tuscany. Biological Invasions 12, 2959-2965.

Pyšek, P., Sádlo, J., Mandák, B., 2002: Catalogue of alien plants of the Czech Republic. Preslia, Praha 84, 155-255.

Raab, V.R., 1993: Beitrag zur Kenntnis der Libellenfauna des Pressegger Sees und anderer Gewässer des Gailtales (Kärnten) (Insecta: Odonata). Carinthia II 183/103, 443-452.

Ramey, V., 2009: Pistia stratiotes, Non-Native to Florida. In: Ramey, V. (ed.), Center for aquatic and invasive plants, University of Florida, Florida. Retrieved September 11, 2019 from http://plants.ifas.ufl.edu/node/328.

Seliškar, A., 1984: Vegetation of the Sava river oxbow lake and its neighbouhood at Prilipe near Čatež. Biološki inštitut, ZRC SAZU, Ljubljana (in Slovenian).

Shawish, T.E., 2004: Marketing network in Thermal Spa Čatež. BSc Thesis. Faculty of Economics. University of Ljubljana, Ljubljana (in Slovenian).

Simon, T., 2000: A guide to the identification of the Hungarian vascular flora. Nemzeti Tankönyvkiadó, Budapest (in Hungarian).

STATISTICA 1995: Statistics II, $2^{\text {nd }}$ ed., StatSoft, Inc., Tulsa.

Šajna, N., Haler, M., Škornik, S., Kaligarič, M., 2007: Survival and expansion of Pistia stratiotes L. in a thermal stream in Slovenia. Aquatic Botany 87, 75-79.

Urbanič, G., Toman, J.M., 2003: Conservation of continental waters. Študentska založba, Ljubljana (in Slovenian).

Zuellig, R.E., Pineda, P.M., Kondratieff, B.C., 2002: Aquatic insects of a High Plains spring: Warm Springs, Guernsey, Wyoming. Journal of the Kansas Entomological Society 75, 163-171.

Živković, M.M., Anđelković, A.A., Cvijanović, D.L., Novković, M.Z., Vukov, D.M., Šipoš, Š.Š., Ilić, M.M., Pankov, N.P., Miljanović, B.M., Marisavljević, D.P., Pavlović, D.M., Radulović, S.B., 2019: The beginnings of Pistia stratiotes L. invasion in the lower Danube delta: the first record for the Province of Vojvodina (Serbia). BioInvasions Records 8, 218-229. 